\title{
PENGARUH KEPADATAN PENDUDUK, KEMISKINAN DAN PERTUMBUHAN EKONOMI TERHADAP KRIMINALITAS
}

\author{
Shinta Wulan Dari 1)*, Asnidar 1) \\ 1) Fakultas Ekonomi, Universitas Samudra \\ *Penulis Korespondensi: wulandarisintaa01@gmail.com, asnidar@unsam.ac.id
}

\begin{abstract}
The purpose of this study was to determine the effect of population density, poverty and economic growth on crime in the city of Langsa. This type of research is descriptive quantitative research. The type of data is secondary data. This study uses a multiple linear regression approach. The results of this study indicate that population density has a positive and significant effect on crime in the city of Langsa, poverty has a negative and significant effect on crime in the city of Langsa, ang economic growth has a positive and insignificant effect on crime in the city of Langsa. Therefor, it is hoped that the government can encourage stable economic growth, government programs that must side with the poor with equitable budget allocations and equitable distribution of population and infrastructure.
\end{abstract}

Keywords: Population Density, Proverty, Economic Growth and Crime

\begin{abstract}
ABSTRAK
Tujuan dari penelitian ini adalah untuk mengetahui Pengaruh Kepadatan Penduduk, Kemiskinan Dan Pertumbuhan Ekonomi Terhadap Kriminalitas Di Kota Langsa. Jenis penelitian ini adalah deskriptif kuantitaif. Jenis data adalah data sekunder. Penelitian ini menggunakan data time series yaitu menggunakan 5 Kecamatan di Kota Langsa dengan menggunakan pendekatan regresi linear berganda. Hasil penelitian ini menunjukkan bahwa Kepadatan Penduduk berpengaruh positif dan signifikan terhadap Kriminalitas di Kota Langsa, Kemiskinan berpengaruh negatif dan signifikan terhadap Kriminalitas di Kota Langsa, dan Pertumbuhan Ekonomi berpengaruh positif dan tidak signifikan terhadap Kriminalitas di Kota Langsa. Oleh sebab itu, diharapkan kepada pemerintah agar dapat mendorong pertumbuhan ekonomi yang stabil, program pemerintah yang harus berpihak pada masyarakat miskin dengan alokasi anggaran yang merata dan pemerataan penduduk serta infrastrukturnya.
\end{abstract}

Kata Kunci: Kepadatan Penduduk, Kemiskinan, Pertumbuhan Ekonomi dan Kriminalitas

Article Information:

Received Date: 19 Januari 2022

Revised Date: 3 Februari 2022

Accepted Date: 24 Februari 2022 


\section{PENDAHULUAN}

\section{Latar Belakang Masalah}

Kriminalitas adalah salah satu masalah yang sering dihadapi disetiap Provinsi Aceh khususnya di Kota Langsa. Kriminalitas di Kota Langsa pada tahun 2011 sampai tahun 2020 mengalami fluktuasi. Secara teoritis, menurut statistik kriminalitas merupakan perkembangan jumlah kejahatan yang ada di Indonesia. Pada tahun 2017-2019 kriminalitas di Kota Langsa menurun, jumlah kejadian tindak kejahatan pada tahun 2017 sebanyak 336.652 kejadian, menurun sebanyak 294.281 pada tahun 2018 dan pada tahun 2019 menurun kembali menjadi 269.324 kejadian kejahatan. Khan (2015) juga mengatakan bahwa cara yang dapat dipakai untuk menekan kejahatan yaitu dengan cara memberi hukuman ataupun meningkatkan upah pendapatan. Salah satunya dengan meningkatkan jumlah kualitas sumber daya manusia melalui pendapatan. Tingginya angka kriminalitas disebabkan oleh beberapa faktor ekonomi contohnya pertumbuhan ekonomi, kemiskinan dan kepadatan penduduk. Ali Khan (2005) juga mengatakan bahwa cara yang dapat dipakai untuk menekan kejahatan yaitu dengan cara memberi hukuman ataupun meningkatkan upah pendapatan. Salah satunya dengan meningkatkan jumlah kualitas sumber daya manusia melalui pendapatan.

Pertumbuhan ekonomi berpengaruh terhadap peningkatan jumlah penduduk, dan angkatan kerja. Secara teoritis menurut Wahid et al (2010) permintaan terhadap kebutuhan tenaga kerja yang rendah dapat $b$ terjadi dikarenakan tidak seimbangnya supply-demand pertumbuhan ekonomi, sehingga tingkat pengangguran akan meningkat. Keadaan seseorang yang tidak memiliki pekerjaan atau pengangguran yang tidak memiliki penghasilan, maka tidak dapat memenuhi kebutuhan hidupnya sesuai syarat hidup layak.
Kemiskinan juga masih menjadi masalah di Provinsi Aceh khususnya di Kota Langsa. Tingkat kemiskinan di Kota Langsa masih terus mengalami fluktuatif, tingkat kemiskinan yang sifatnya fluktuatif juga berdampak pada kriminalitas. Secara teoritis, kemiskinan berpengaruh signifikan terhadap kriminalitas seperti yang dinyatakan oleh Rahmalia et al (2019) dan Kartini (2005). Kartini (2005) menyarankan agar pemerintah dapat mengentaskan kemiskinan di Indonesia saat ini, baik dengan penyaluran subsidi bantuan sosial dan lainnya agar semakin merata. Rahmalia et al (2019) juga menyarankan agar pemerintah dapat mengentas kemiskinan yang terjadi di Indonesia saat ini seperti bantuan sosial, bantuan PKH, dan lain sebagainya.

Selain itu kepadatan penduduk juga identik dengan kriminalitas. Hal itu terjadi karena tingginya angka pengangguran disuatu wilayah yang terus meningkat setiap tahunnya. Hardianto (2009), mengatakan bahwa kejahatan pada dasarnya timbul akibat karakter manusia yang didorong oleh masalah ekonomi dan berpendapatan yang rendah sehingga menimbulkan tindakan kriminalitas untuk mendapatkan kepuasan.

Berdasarkan pemaparan fenomena di atas penulis tertarik melakukan penelitian dengan judul "Pengaruh Kepadatan Penduduk, Kemiskinan, Pertumbuhan Ekonomi Terhadap Kriminalitas Di Kota Langsa".

\section{TINJAUAN PUSTAKA \\ Kriminalitas}

Menurut Kartini (2005) kriminalitas adalah tindak kejahatan yang dilakukan secara sadar dan tidak sadar baik oleh pria ataupun wanita yang merugikan orang lain. Kriminalitas bukan warisan tetapi hukum karena kejahatan. Kriminalitas juga memiliki arti yuridis formal dan sosiologis. Yuridis formal adalah sikap yang melanggar moral serta norma kemanusiaan, merugikan masyarakat, melanggar hukum dan UU tentang tindak 
pidana. Sedangkan sosiologis yaitu segala bentuk lisan, perbuatan, serta tingkah laku baik secara politis ataupun ekonomis yang dapat merugikan masyarakat Hardianto (2009)

Menurut Badan Pusat Statistik (2010), indikator yang digunakan untuk mengukur kejahatan secara umum adalah :

a. Angka jumlah kejahatan (Crime total)

b. Selang waktu terjadinya suatu tindak kejahatan (Crime clock)

c. Jumlah orang yang beresiko terkena tindak kejahatan ( Crime rate)

Menurut Silvia \& Ikhsan (2021) dalam penelitiannya yang berjudul "Pengaruh Pertumbuhan Ekonomi, Kemiskinan dan Kepadatan Penduduk Terhadap Kriminalitas di Indonesia" menyatakan bahwa faktor yang mempengaruhi kriminalitas yaitu pertumbuhan ekonomi, kemiskinan dan kepadatan penduduk berpengaruh positif dan signifikaan terhadap kriminalitas.

\section{Faktor yang Mempengaruhi Terjadinya Kriminalitas}

Ada beberapa faktor yang mempengaruhi terjadinya kriminalitas yaitu baik factor intern maupun ekstern yang dapat menyebabkan seseorang melakukan tindakan kriminal. Faktor internal terdiri dari faktor kebutuhan ekonomi yang mendesak, faktor ketanagakerjaan (pengangguran atau memiliki pekerjaan), dan faktor taraf kesejahteraan. Faktor eksternal terdiri dari faktor pendidikan, dan faktor pergaulan atau pengaruh lingkungan. Jumlah penduduk yang tinggi pada suatu daerah dapat dikaitikan dengan angka kejahatan yang tinggi pada daerah tersebut. Hal ini juga diikuti dengan angka Penyandang Masalah Kesejahteraan Sosial (PMKS) yang tinggi. Tak jarang PMKS menjadi pelaku kejahatan jika tidak diatasi dengan baik Handayani (2017).

\section{Jenis-jenis Kriminalitas}

Menurut Bjorn Lomborg (2002), kriminalitas memiliki 4 jenis antara lain:
1. Brown Criminal ialah orang berdasarkan pada doktrin atavisme (adanya sifat hewani yang diturunkan pada diri seseorang).

2. Nsane criminal ialah orang-orang yang ttergolong ke dalam kelompok idiot, embisil atau paranoid.

3. Occasional criminal atau crim inaloid yaitu pelaku kejahatan berdasarkan pengalaman yang terus-menerus sehingga dapat mempengaruhi pribadinya.

4. Riminals of passion ialah pelaku kejahatan yang melakukan tindakannya karena marah, cinta ataupun karena kehormatan.

\section{Kepadatan Penduduk}

Hardianto (2009) mengemukakan pendapat bahwa peningkatan jumlah penduduk yang cepat akan berdampak pada tingkat kepadatan penduduk di daerah tersebut. Hal ini dapat terjadi akibat penduduk yang bertambah sementara ruang ataupun lahan masih bersifat tetap. Tingginya kepadatan penduduk yang tidak diimbangi dengan persebaran penduduk dikhawatirkan dapat terjadi ledakan di wilayah tersebut.

Menurut Mantra (2007) mengatakan bahwa kepadatan penduduk adalah perbandingan antara jumlah penduduk dengan luas wilayah yang dialami. Menurut Irhamni (2017), tingginya tingkat kelahiran adalah penyumbang utama terjadinya pertumbuhan kota yang sangat cepat. Ledakan penduduk di kota-kota di negara berkembang menjadi hambatan dalam meningkatkan kesejahteraan masyarakat yang ada di kota.

\section{Dampak Kepadatan Penduduk Yang Dapat Memicu Terjadinya Kriminalitas}

Kepadatan penduduk merupakan salah satu factor yang dapat memicu tindakan criminal karena daerah yang penduduknya sangat padat cenderung mengalami permasalahan ekonomi, kesejahtreraan, kebutuhan pangan, dan kurangnya tingkat keamanan yang berujung pada tindak criminal. Jumlah penduduk yang semakin tinggi di suatu daerah akan mengakibatkan lapangan kerja 
yang semakin berkurang dan dapat menyebabkan pengangguran serta ketimpangan pendapatan antara tenaga kerja yang bekerja dan tidak bekerja, hal seperti dapat mendorong seseorang untuk melakukan tindak criminal Edwart, A. O., \& Azhar (2019). Menurut teori kependudukan Thomas Robert Malthus, pertumbuhan penduduk harus seimbang dengan pertumbuhan bahan makanan. Ia berpendapat bahwa laju pertumbuhan makanan jauh lebih lambat dibandingkan dengan laju pertumbuhan penduduk. Lapangan pekerjaan yang semakin menurun akan meningkatkan jumlah pengangguran, sehingga timbul berbagai macam aksi kriminalitas. Dengan begitu, sudah jelas bahwa kepadatan penduduk menyebabkan tingkat pengangguran yang tinggi dan sejalan dengan tingkat kriminalitas Handayani (2017).

Kepadatan penduduk yang tinggi dapat mengahmbat usaha peningkatan kualitas penduduk. Hal ini berhubungan dengan teori kependudukan kontemporer John Stuart Mill yang menyarankan untuk meningkatkan tingkat golongan yang tidak mampu (pekerjaan, kesehatan, pendidikan, pendapatan). Seperti yang kita ketahui bahwa kepadatan penduduk memiliki pengaruh positif terhadap tingkat kriminalitas terutama pada daerah yang diikuti dengan peningkatan kemiskinan. Kepadatan penduduk dan kendala yang dihadapi oleh pemerintah untuk mengatur populasi semakin meningkat setiap tahunnya Fajri \& Rizki (2019). Menurut Christiani, C., Tedjo, P., \& Martono (2014), kepadatan penduduk juga menyebabkan fasilitas sosial dan kesehatan (sekolah, rumah sakit, tempat rekreasi) serta fasilitas pendukung kehidupan lainnya tidak tercukupi. Sebagian penduduk yang tidak mendapat fasilitas tersebut akhirnya mencari cara lain agar mendapat fasilitas yang sama, yaitu dengan melakukan tindakan kriminal.

\section{Kemiskinan}

Kemiskinan merupakan sebagai kondisi deprivassi materi dan sosial yang menyebabkan individu hidup dibawah standar kehidupan yang layak atapun kondisi dimana individu mengalami deprivassi relatif dibandingkan individu lainnya dalam masyarakat (Hall, A \& Midgley, 2014). Menurut Badan Pusat Statistik (2016) kemiskinan merupakan ketidakmampuan dari sisi ekonomi, materi dan fisik untuk mencukupi kebutuhan dasar makanan dan bukan makanan yang diukur dengan pengeluaran.

Kuncoro (2006), mengartikan kemiskinan sebagai ketidakmampuan untuk memenuhi standar hidup minimum. Todaro, Michael (2000) juga menyatakan bahwa kemiskinan absolut artinya apabila sejumlah penduduk yang tidak mampu mendapatkan sumber daya yang cukup untuk memenuhi kebutuhan dasar. Mereka hidup dibawah tingkat pendapatan riil minimum tertentu atau dibawah garis kemiskinan internasional. Seseorang dapat dikatakan miskin secara absolut apabila tingkat pendapatannya berada dibawah garis kemiskinan atau sejumlah pendapatannya yang tidak cukup untuk memenuhi kebutuhan hidup minimal, seperti sandang, pangan, Kesehatan, perumahan serta Pendidikan yang diperlukan untuk dapat hidup dan bekerja.

\section{Penyebab Kemiskinan}

Suwandi (2015) kemiskinan di sebabkan oleh dua hal antara lain yang pertama kemiskinan di sebabkan karena sifat alami, sifat yang timbul dari perilaku masyarakat atau seseorang yaitu:

1. Keterbatasan sumber daya modal, keterbatasan sumber daya manusia (SDM) dapat di artikan kualitas sumber daya manusia misalkan keterampilan, pendidikan, dan pengetahuan.

2. Tempat atau letak geografis suatu wilayah yang terpencil dan yang sulit untuk di jangkau, yang mengakibatkan sulit berinteraksi dengan penduduk yang maju.

Yang kedua yaitu kemiskinan yang di sebabkan karena kebijakan pembangunan atau kebijakan pemerintah, dapat di lihat dari berbagai aspek yaitu : 
1. Pembangunan yang kurang memperhatikan kawasan atau wilayah yang terpencil dan sulit di jangkau.

2. Adanya ketimpangan antara pembangunan di wilayah desa maupun kota.

3. Kurang memperhatikan usaha maupun produk masyarakat yang berskala kecil atau usaha mikro ekonomi.

\section{Pertumbuhan Ekonomi}

Pertumbuhan ekonomi dapat diartikan sebagai perkembangan kegiatan dalam perekonomian yang menyebabkan barang dan jasa yang diproduksi dalam masyarakat bertambah serta kemakmuran masyarakat menjadi meningkat (Sadono, 2011). Pertumbuhan ekonomi juga merupakan suatu proses yang mantap dimana kapasitas produktif dari suatu perekonomian meningkat sepanjang waktu untuk menghassilkan tingkat pendapatan yang lebih besar Todaro (2003).

Teori Sollow membuktikan bagaimana tingkat tabungan, investasi, pertumbuhan populasi serta kemajuan teknologi dapat mempengaruhi tingkat output perekonomian dan pertumbuhan ekonomi. Harrod Domar juga membuktikan bahwa semakin banyak jumlah PDB yang ditabung maka akan menambah modal sehingga dapat meningkatkan pertumbuhan ekonomi. Pertumbuhan ekonomi di butuhkan karena sumber utama peningkatan standar hidup. Kemampuan suatu negara untuk meningkatkan standar hidup penduduknya yaitu sangat tergantung dan di tentukan oleh laju pertumbuhan ekonomi. Pertumbuhan ekonomi merupakan peningkatan kemampuan dari suatu perekonomian dalam memproduksi barang, jasa, pertumbuhan ekonomi lebih menunjuk perubahan yang bersifat kuantitatif Nanga (2001). Tingkat pertumbuhan ekonomi dan kemiskinan merupakan tolak ukur untuk melihat keberhasilan atau kemakmuran suatu daerah. Seluruh daerah yang mengalami laju pertumbuhan ekonomi yang kurang maksimal akan berusaha sebaik mungkin untuk mencapai suatu pertumbuhan ekonomi yang maksimal dan menurunkan kemiskinan Jonaidi A (2012)

\section{Faktor-faktor yang Mempengaruhi Pertumbuhan Ekonomi}

Pertumbuhan ekonomui juga dipengaruhi oleh berbagai factor antara lain:

1. Barang modal dan teknologi

Modal dan barang yang semakin meningkat dan bertambah yang di dukung dengan teknologi yang maju maka dapat menciptakan sebuah inovasi maupun karya yang dapat meningkatkan produksi.

2. Sumber daya alam

Sumber daya alam jika di kelola serta di manfaatkan dengan baik, maka dapat meningkatkan pendapatan serta mendorong pertumbuhan ekonomi.

3. Sikap masyarakat

Sikap hemat, disiplin, serta mampu bekerja keras, suka berinvestasi, maka dapat menunjang pertumbuhan ekonomi, sedangkan jika sulit menerima pembaharuan serta perubahan cara hidup modern maka dapat menghambat pertumbuhan.

4. Kualitas dan kuantitas penduduk

Kualitas penduduk merupakan penduduk yang memiliki keterampilan serta keahlian, mempunyai etos kerja yang tinggi maka dapat mendorong pertumbuhan ekonomi. Sedangkan kuantitas penduduk merupakan jumlah penduduk yang mengalami peningkatan dan pendorong utama dalam meningkatkan ekonomi, akan tetapi jumlah penduduk memiliki dampak positif dan negatif. Dampak positifnya merupakan penduduk yang meningkat membuat tenaga kerja bertambah sehingga dapat meningkatkan produksi. Sedangkan dampak negatifnya yaitu jika penduduk tinggi dan perekonomiannya masih rendah maka 
dapat mengakibatkan beban suatu daerah, karena hasil produksi yang minim tidak dapat mencukupi kebutuhan hidup.

\section{HUBUNGAN ANTARA KEPADATAN PENDUDUK DENGAN KRIMINALITAS}

Menurut Silvia \& Ikhsan (2021), adanya keterkaitan hubungan antara kepadatan penduduk dengan kriminalitas sebagai berikut: "kepadatan penduduk berpengaruh positif dan signifikan terhadap kriminalitas". Dimana dapat dijelaskan bahwa semakin tinggi jumlah kepadatan penduduk maka akan menyebabkan kriminalitas meningkat.

Hardianto (2009) berpendapat bahwa peningkatan jumlah penduduk yang cepat akan berdampak pada tingkat kepadatan penduduk di daerah tersebut. Hal ini dapat terjadi akibat penduduk yang bertambah sementara ruang ataupun lahan masih bersifat tetap. Tingginya kepadatan penduduk yang tidak diimbangi dengan persebaran penduduk dikhawatirkan dapat terjadi ledakan di wilayah tersebut. Kepadatan penduduk juga merupakan salah satu faktor yang dapat memicu tindakan kriminal karena daerah yang penduduknya sangat padat cenderung mengalami permasalahan ekonomi, kesejahtreraan, kebutuhan pangan, dan kurangnya tingkat keamanan yang berujung pada tindak criminal. Jumlah penduduk yang semakin tinggi di suatu daerah akan mengakibatkan lapangan kerja yang semakin berkurang dan dapat menyebabkan pengangguran serta ketimpangan pendapatan antara tenaga kerja yang bekerja dan tidak bekerja, hal seperti dapat mendorong seseorang untuk melakukan tindak criminal Edwart, A. O., \& Azhar (2019).

\section{HUBUNGAN ANTARA KEMISKINAN DENGAN KRIMINALITAS}

Menurut Silvia \& Ikhsan (2021), adanya keterkaitan hubungan antara kemiskinan dengan kriminaloitas sebagai berikut: "kemiskinan memiliki hubungan yang signifikan terhadap kriminalitas". Dimana dapat dijelaskan bahwa semakin tinggi angka kemiskinan maka dapat menyebabkan kriminalitas meningkat. Kemiskinan memiliki arti sebagai kondisi deprivassi materi dan sosial yang menyebabkan individu hidup dibawah standar kehidupan yang layak atapun kondisi dimana individu mengalami deprivassi relatif dibandingkan individu lainnya dalam masyarakat Hall, A \& Midgley (2014).

Suwandi (2015)Kemiskinan di sebabkan oleh dua hal antara lain yang pertama kemiskinan di sebabkan karena sifat alami, sifat yang timbul dari perilaku masyarakat atau seseorang. Yang kedua yaitu kemiskinan yang di sebabkan karena kebijakan pembangunan atau kebijakan pemerintah.

\section{HUBUNGAN ANTARA PERTUMBUHAN EKONOMI DENGAN KRIMINALITAS}

Menurut Silvia \& Ikhsan (2021), adanya keterkaitan hubungan antara pertumbuhan ekonomi dengan kriminalitas sebagai berikut: "pertumbuhan ekonomi memiliki hubungan yang signifikan terhadap kriminalitas". Dimana dapat dijelaskan bahwa semakin tinggi pertumbuhan ekonomi maka dapat menyebabkan kriminalitas meningkat. Pertumbuhan ekonomi dapat diartikan sebagai perkembangan kegiatan dalam perekonomian yang menyebabkan barang dan jasa yang diproduksi dalam masyarakat bertambah serta kemakmuran masyarakat menjadi meningkat Sadono (2011). Teori Sollow membuktikan bagaimana tingkat tabungan, investasi, pertumbuhan populasi serta kemajuan teknologi dapat mempengaruhi tingkat output perekonomian dan pertumbuhan ekonomi. 


\section{METODE PENELITIAN}

\section{Lokasi Penelitian}

Penelitian ini dilakukan di Kota Langsa dengan ruang lingkup penelitian merupakan kajian dari ekonomi kependudukan. Penelitian ini menganalisis tentang Pengaruh Kepadatan Penduduk, Kemiskinan, dan Pertumbuhan Ekonomi Terhadap Kriminalitas Di Kota Langsa.

\section{Metode Analisis Data}

Teknik analisis data yang digunakan dalam penelitian ini yaitu regresi linear berganda dengan menggunakan metode data time series untuk melihat pengaruh kepadatan penduduk, kemiskinan, dan pertumbuhan ekonomi terhadap kriminalitas. Adapun menurut Gurajati (2013) bentuk model regresi linear berganda yang sudah ditransformasikan yaitu :

$$
\mathbf{Y}=\boldsymbol{\beta}_{\mathbf{0}}+\boldsymbol{\beta}_{1} \mathbf{X}_{1}+\mathbf{B}_{2} \mathbf{X}_{2}+\boldsymbol{\beta}_{3} \mathbf{X}_{3}+\mathbf{e}
$$

Kemudian ditransformasikan sehingga mudah untuk diinterpretasikan menjadi

$$
T d k=\beta^{0}+\beta_{1} K P+\beta_{2} K M S+B_{3} P E+e
$$

\begin{tabular}{|c|c|}
\hline Tdk & $=$ Tindak kriminalitas (kasus) \\
\hline KP & $=$ Kepadatan penduduk \\
\hline KMS & $=$ Kemiskinan \\
\hline PE & $=$ Pertumbuhan ekonomi \\
\hline$\beta_{0}$ & $=$ Konstanta \\
\hline$\beta_{1}, \beta_{2}, \beta_{3}$ & $\begin{aligned}= & \text { Koefisien regresi linear } \\
& \text { berganda }\end{aligned}$ \\
\hline & $=$ Error term \\
\hline
\end{tabular}

Keterangan :

\section{HASIL DAN PEMBAHASAN}

\section{Uji Asumsi Klasik}

\section{Uji Normalitas}

Dalam penelitian ini metode yang digunakan untuk uji normalitas adalah dengan statistik Jarque-Bera dimana pada Gambar 1 dan tabel 1 hasilnya menunjukkan nilai statistik Jarque-Bera hasil bahwa nilai probabilitasnya adalah $0,543969>\alpha=0,05$, hal ini bermakna bahwa residual data yang digunakan adalah berdistribusi normal dan layak digunakan untuk memprediksi.

Tabel 1. Hasil Uji Normalitas Residual

\begin{tabular}{|l|l|}
\hline Jarque - Bera & 1.217725 \\
\hline Probability & 0.543969 \\
\hline
\end{tabular}

Sumber : Data penelitian (diolah 2022)

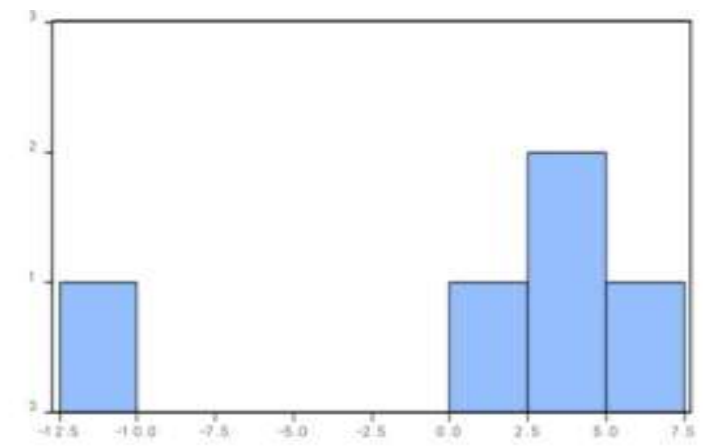

Gambar 1. Hasil Uji Normalitas Residual

\section{Uji Multikolinearitas}

Model regresi yang baik adalah regresi yang tidak ada gejala korelasi yang kuat diantara variabel bebasnya. Model regresi yang baik seharusnya tidak terjadi korelasi diantara variabel bebasnya.

Tabel 2. Hasil Uji Multikolinearitas

\begin{tabular}{|c|c|c|}
\hline Variable & $\begin{array}{c}\text { Coefficient } \\
\text { Variance }\end{array}$ & Centered VIF \\
\hline C & 93861.23 & NA \\
\hline KP & 0.076244 & 2.036684 \\
\hline KMS & 1009429. & 1.377680 \\
\hline PE & 12.35238 & 1.609930 \\
\hline
\end{tabular}

Sumber : Data penelitian (diolah 2022)

Dari tabel 2 dapat dijelaskan bahwa hasil estimasi nilai matriks korelasi menunjukkan tidak terdapat masalah multikolinearitas data. Karena nilai Kepadatan Penduduk yaitu sebesar $2,037<10$, Kemiskinan memiliki nilai sebesar $1.378<10$, dan Pertumbuhan ekonomi memiliki nilai sebesar 1,609 maka dapat dinyatakan bahwa variabel dalam penelitian ini tidak terdapat masalah multikolinearitas dalam model prediksi. 


\section{Uji Heteroskedastisitas}

Heteroskedastisitas merupakan keadaan dimana semua gangguan yang muncul dalam fungsi regresi populasi tidak memiliki varians yang sama. Adapun hasil uji heteroskedastisitas dalam penelitian ini dapat dijelaskan pada tabel berikut ini :

Tabel 3. Hasil Uji Heteroskedastisitas

Heteroskedasticity Test: Breusch-Pagan-

Godfrey

\begin{tabular}{|c|c|c|c|}
\hline F-statistic & 0.096895 & Prob. F & 0.9511 \\
\hline $\begin{array}{c}\text { Obs*R- } \\
\text { squared }\end{array}$ & 1.126091 & $\begin{array}{c}\text { Prob. } \\
\text { Chi- } \\
\text { Square }\end{array}$ & 0.7708 \\
\hline $\begin{array}{c}\text { Scaled } \\
\text { explained SS }\end{array}$ & 0.042375 & $\begin{array}{c}\text { Prob. } \\
\text { Chi- } \\
\text { Square }\end{array}$ & 0.9977 \\
\hline
\end{tabular}

Sumber : Data penelitian (diolah 2022)

Dari tabel 3 diketahui bahwa nilai prob. Chi-Square pada $O b s^{*} R$-squared sebesar $0,7708>0,05$, artinya model regresi bersifat homokedastisitas atau dengan kata lain tidak ada masalah asumsi non heteroskedastisita.

\section{Analisis Regresi Linear Berganda}

Analisis regresi linear berganda digunakan untuk mengetahui pengaruh variabel bebas yaitu Kepadatan Penduduk Kemiskinan dan Pertumbuhan Ekonomi terhadap variabel terikat yaitu Kriminalitas. Hasil regresi dianalisis menggunakan program pengolah data software Eviews 10 sehingga diperoleh hasil seperti pada tabel berikut ini :

Tabel 4. Regresi Linear Berganda

\begin{tabular}{|c|c|c|}
\hline Variable & Coefficient & Prob. \\
\hline $\mathrm{C}$ & 4174.889 & 0.0466 \\
\hline $\mathrm{KP}$ & 6.178518 & 0.0284 \\
\hline $\mathrm{KMS}$ & -23688.12 & 0.0270 \\
\hline $\mathrm{PE}$ & 31.62366 & 0.0705 \\
\hline \multicolumn{2}{|c|}{ R-squared } & 0.998618 \\
\hline \multicolumn{2}{|c|}{ Adjusted R-squared } & 0.994471 \\
\hline \multicolumn{2}{|c|}{ Prob(F-statistic) } & 0.047325 \\
\hline
\end{tabular}

Sumber : Data penelitian (diolah 2022)
Berdasarkan tabel 4 hasil analisis dapat dibuat persamaan regresi linier berganda sebagai berikut :

$$
\mathrm{Tdk}=4.174,89+6,18 \mathrm{KP}-23.688,12 \mathrm{KMS}+
$$

$$
31,62 \mathrm{PE}+\mathrm{e}
$$

Dari hasil persamaan tersebut maka dapat diinterprestasikan sebagai berikut :

1. Nilai konstanta sebesar 4.174,89 menunjukkan bahwa jika variabel kepadatan penduduk, kemiskinan dan pertumbuhan ekonomi tetap maka tingkat kriminalitas di Kota Langsa sebesar 4.174,89 jiwa.

2. Nilai Unstandardized Coefficients kepadatan penduduk sebesar 6,18 menunjukkan bahwa apabila terjadi peningkatan kepadatan penduduk 1 persen, maka akan menyebabkan tindak kriminalitas di Kota Langsa meningkat 6,18 kasus, dengan asumsi kemiskinan dan pertumbuhan ekonomi tetap (cateris paribus).

3. Nilai Unstandardized Coefficients kemiskinan sebesar -23.688,12 menunjukkan bahwa apabila terjadi peningkatan kemiskinan sebesar 1 persen, maka akan menyebabkan tindak kriminalitas di Kota Langsa menurun 23.688,12 kasus, dengan asumsi kepadatan penduduk dan pertumbuhan ekonomi tetap (cateris paribus).

4. Nilai Unstandardized Coefficients $\mathrm{X}_{3}$ sebesar 31,62 menunjukkan bahwa apabila terjadi peningkatan pertumbuhan ekonomi sebesar 1 persen, maka akan menyebabkan tindak kriminalitas di Kota Langsa meningkat sebesar 31,62 kasus, dengan asumsi kepadatan penduduk dan kemiskinan tetap (cateris paribus).

\section{Uji t}

Berdasarkan tabel 4 maka dapat diketahui bahwa hasil estiminasi koefisien variabel kepadatan penduduk sebesar 6,18 dan signifikan pada Prob. 0,0284 $<\alpha=0,05$. Artinya secara parsial kepadatan penduduk bepengaruh positif dan signifikan terhadap 
tindak kriminalitas di Kota Langsa. Jika terjadi peningkatan kepadatan penduduk sebesar 1 persen, maka tindak kriminalitas di Kota Langsa akan meningkat secara signifikan sebesar 6,18 kasus.

Hasil estiminasi koefisien variabel kemiskinan sebesar $-23.688,12$ dan signifikan pada Prob. $0,0270<\alpha=0,05$. Artinya secara parsial kemiskinan bepengaruh negatif dan signifikan terhadap tindak kriminalitas di Kota Langsa. Jika terjadi peningkatan kemiskinan sebesar 1 persen, maka tindak kriminalitas di Kota Langsa akan menurun secara signifikan sebesar 23.688,12 kasus.

Hasil estiminasi koefisien variabel pertumbuhan ekonomi sebesar 31,62 dan signifikan pada Prob. 0,0705> $>=0,05$. Artinya secara parsial pertumbuhan ekonomi bepengaruh positif dan tidak signifikan terhadap tindak kriminalitas di Kota Langsa. Jika terjadi peningkatan pertumbuhan ekonomi sebesar 1 persen, maka tindak kriminalitas di Kota Langsa akan meningkat secara tidak signifikan sebesar 31,62 kasus.

\section{Uji F}

Berdasarkan tabel 4 maka diperoleh hasil uji secara simultan dengan nilai Prob. 0,047325 $<\alpha=0,05$. Maka dapat dinyatakan secara simultan kepadatan penduduk, kemiskinan dan pertumbuhan ekonomi berpengaruh signifikan terhadap tindak kriminalitas di Kota Langsa.

\section{Koefisien Determinasi $\left(\mathbf{R}^{2}\right)$}

Koefisien detreminasi $\left(\mathrm{R}^{2}\right)$ dalam penelitian ini diperoleh nilai $R$-squared sebesar 0,9986 atau $99,86 \%$, artinya variabel kepadatan penduduk kemiskinan dan pertumbuhan ekonomi mempengaruhi tindak kriminalitas di Kota Langsa sebesar 99,86\%, sedangkan sisanya sebesar $0,14 \%$ dipengaruhi oleh faktorfaktor lain di luar penelitian, seperti jumlah prnduduk, pendidikan dan pengangguran.

\section{Pembahasan}

\section{Pengaruh Kepadatan Penduduk Terhadap Kriminalitas}

Pernyataan hipotesis pertama menyatakan bahwa kepadatan penduduk berpengaruh signifikan terhadap pertumbuhan ekonomi di Kota Langsa. Besaran pengaruh kepadatan penduduk terhadap pertumbuhan ekonomi adalah 6,18 dengan nilai signifikan pada prob. $0,0284<\alpha=0,05$ maka hipotesis dalam penelitian ini diterima. Dengan demikian dapat disimpulkan bahwa kepadatan penduduk berpengaruh positif dan signifikan terhadap kriminalitas di Kota Langsa. Ini berarti jika terjadi peningkatan kepadatan penduduk sebesar 1 persen maka akan meningkat secara signifikan sebesar 6,18 kasus, dengan asumsi variabel lain konstan.

Kepadatan penduduk merupakan banyaknya penduduk dengan tingkat perbandingan antara jumlah penduduk dan luas wilayah. Fajri \& Rizki (2019) mengemukakan pendapat bahwa peningkatan jumlah penduduk yang cepat akan berdampak pada tingkat kepadatan penduduk di daerah tersebut. Hal ini dapat terjadi akibat penduduk yang bertambah sementara ruang aataupun lahan masih bersifat tetap. Tingginya kepadatan penduduk yang tidak diimbangi dengan persebaran penduduk dan ketersediaan lapangan pekerjaan sehingga mengakibatkan tindak kriminalitas akan meningkat.

Hasil penelitian sama dengan penelitian yang dilakukan oleh Silvia \& Ikhsan (2021), Fajri \& Rizki (2019), Purwanti \& Widyaningsih (2019), Sabiq \& Apsari (2021)yang menunjukkan kepadatan penduduk berpengaruh positif dan signifikan terhadap kriminalitas.

\section{Pengaruh Kemiskinan Terhadap Kriminalitas}

Pernyataan hipotesis kedua menyatakan bahwa kemiskinan berpengaruh signifikan terhadap kriminalitas di Kota Langsa. Besaran pengaruh kemiskinan terhadap kriminalitas adalah $-23.688,12$ dengan nilai signifikan pada prob. $0,0270<\alpha=0,05$ maka hipotesis dalam 
penelitian ini diterima. Dengan demikian dapat disimpulkan bahwa kemiskinan berpengaruh negatif dan signifikan terhadap kriminalitas di Kota Langsa. Jika terjadi penurunan kemiskiman sebesar 1 persen, kriminalitas di Kota Langsa akan meningkat secara signifikan sebesar 23.688,12 kasus, dengan asumsi variabel lain konstan.

Kuncoro (2006), mengartikan kemiskinan sebagai ketidakmampuan untuk memenuhi standar hidup minimum. Todaro, Michael (2000) juga menyatakan bahwa kemiskinan absolut artinya apabila sejumlah penduduk yang tidak mampu mendapatkan sumber daya yang cukup untuk memenuhi kebutuhan dasar. Mereka hidup dibawah tingkat pendapatan riil minimum tertentu atau dibawah garis kemiskinan internasional. Seseorang dapat dikatakan miskin secara absolut apabila tingkat pendapatannya berada dibawah garis kemiskinan atau sejumlah pendapatannya yang tidak cukup untuk memenuhi kebutuhan hidup minimal, seperti sandang, pangan, Kesehatan, perumahan serta Pendidikan yang diperlukan untuk dapat hidup dan bekerja.

Hasil penelitian ini tidak sesuai dengan penelitian yang dilakukan oleh Silvia \& Ikhsan (2021), Rahmalia et al (2019), Kuciswara et al. (2021), Putra et al., (2021) yang menyatakan bahwa variabel kemiskinan mempunyai pengaruh signifikan terhadap Kriminalitas.

\section{Pengaruh Pertumbuhan Ekonomi Terhadap Kriminalitas}

Pernyataan hipotesis ketiga menyatakan bahwa pertumbuhan ekonomi berpengaruh signifikan terhadap kriminalitas di Kota Langsa. Besaran pengaruh pertumbuhan ekonomi terhadap kriminalitas adalah 31,62 dengan nilai signifikan pada prob. $0,0705>\alpha=0,05$ maka hipotesis dalam penelitian ini ditolak. Dengan demikian dapat disimpulkan bahwa pertumbuhan ekonomi berpengaruh positif dan tidak signifikan terhadap kriminalitas di Kota Langsa. Ini berarti jika terjadi peningkatan pertumbuhan ekonomi sebesar 1 persen maka akan meningkat secara signifikan sebesar
31,6246 kasus dengan asumsi variabel lain konstan.

Pertumbuhan ekonomi juga merupakan suatu proses yang mantap dimana kapasitas produktif dari suatu perekonomian meningkat sepanjang waktu untuk menghassilkan tingkat pendapatan yang lebih besar Todaro (2003).

Teori Sollow membuktikan bagaimana tingkat tabungan, investasi, pertumbuhan populasi serta kemajuan teknologi dapat mempengaruhi tingkat output perekonomian dan pertumbuhan ekonomi. Harrod Domar (1957) juga membuktikan bahwa semakin banyak jumlah PDB yang ditabung maka akan menambah modal sehingga dapat meningkatkan pertumbuhan ekonomi.

Hasil penelitian ini menolak penelitian yang dilakukan oleh Fajri \& Rizki (2019), purwanti \& Widyaningsih (2019), yang menyatkan bahwa variabel pertumbuhan ekonomi memiliki pengaruh signifikan dengan kriminalitas.

\section{KESIMPULAN DAN SARAN}

Berdasarkan hasil analisis data dan pembahasan mengenai pengaruh kepadatan penduduk, kemiskinan dan pertumbuhan ekonomi terhadap kriminalitas di Kota Langsa, maka dapat diperoleh kesimpulan bahwa kepadatan penduduk berpengaruh positif dan signifikan terhadap tindak kriminalitas di Kota Langsa ( $\mathrm{H}_{\mathrm{o}}$ di terima), hasil penelitian ini sama dengan penelitian yang dilakukan oleh Silvia \& Ikhsan (2021), Fajri \& Rizki (2019), Purwanti \& Widyaningsih (2019), Sabiq \& Apsari (2021)yang menunjukkan kepadatan penduduk berpengaruh positif dan signifikan terhadap kriminalitas. Kemiskinan berpengaruh negatif dan signifikan teerhadap kriminalitas di Kota Langsa $\left(\mathrm{H}_{\mathrm{o}}\right.$ di terima), hasil penelitian ini tidak sesuai dengan penelitian yang dilakukan oleh Silvia \& Ikhsan (2021), Rahmalia et al (2019), Kuciswara et al. (2021), Putra et al., (2021) yang menyatakan bahwa variabel kemiskinan mempunyai pengaruh signifikan terhadap Kriminalitas. Pertumbuhan penduduk berpengaruh positif dan tidak signifikan 
terhadap kriminalitas di Kota Langsa $\left(\mathrm{H}_{\mathrm{o}}\right.$ di tolak), hasil penelitian ini menolak penelitian yang dilakukan oleh Fajri \& Rizki (2019), purwanti \& Widyaningsih (2019), yang menyatkan bahwa variabel pertumbuhan ekonomi memiliki pengaruh signifikan dengan kriminalitas.

Adapun saran dari penelitian ini adalah pertumbuhan ekonomi yang stabil sangat diharapakn untuk menekankan angka kriminalitas dengan cara meningkatkan nilai tambah produksi maka dapat meningkatkan pendapatan sehingga kriminalitas di Kota Langsa akan berkurang. Kemiskinan dapat menghambat tujuan pembangunan dan dapat menjadi pendorong timbulnya masalah social, oleh sebab itu sebaiknya pemerataan pembangunan melalui pemberdayaan masyarakat harus tepat sasaran. Diharapkan kepada pemerintah agar dapat mengentaskan kriminalitas dengan cara membuka lapangan pekerjaan yang luas. Diharapkan bagi peneliti selanjutnya apabila ingin meneliti lebih lanjut tentang pengaruh kepadatan penduduk, kemiskinan dan pertumbuhan ekonomi terhadap kriminalitas, untuk menggunakan tahun yang lebih panjang agar dapat menhasilkan penelitian yang lebih mendalam.

\section{REFERENSI}

Ali Khan, S. (2005). Filsafat Pendidikan AlGhazali.

Badan Pusat Statistik. (2010). Kota Langsa Dalam Angka.

Badan Pusat Statistik. (2016). Kota Langsa Dalam Angka.

Bjorn Lomborg. (2002). The Skeptical Environmentalist: Measuring the Real State of the World. Cambrigde University Press.

Christiani, C., Tedjo, P., \& Martono, B. (2014). Analisis Dampak Kepadatan Penduduk Terhadap Kualitas Hidup Masyarakat Provinsi Jawa Tengah. Jurnal Ilmiah UNTAG Semarang, 102-114.

Edwart, A. O., \& Azhar, Z. (2019). Pengaruh Tingkat Pendidikan, Kepadatan Penduduk dan Ketimpangan Pendapatan Terhadap Kriminalitas Di Indonesia. Jurnal Kajian
Ekonomi Dan Pembangunan, 1(3), 759768.

Fajri, \& Rizki. (2019). Pengaruh Pertumbuhan Ekonomi, Kepadatan Penduduk Dan Pengangguran Terhadap Kriminalitas Perkotaan Aceh. 4(3), 255-263.

Gurajati, D. . (2013). Dasar-Dasar Ekonometrika (R. . Mangunsong (ed.); 5th ed.).

Hall, A \& Midgley, J. (2014). Social Policy For Development.

Handayani, R. (2017). Analisis Dampak Kependudukan Terhadap Tingkat Kriminalitas di Provinsi Banten. Jurnal Administrasi Publik, 8(2), 149-169.

Hardianto, F. (2009). Analisis Faktor-Faktor Yang Mempengaruhi Tingkat Kriminalitas Di Indonesia Dari Pendekatan Ekonomi.

Irhamni. (2017). Pengaruh Jumlah Penduduk, Pengangguran dan Pengeluaran Pemerintah Terhadap Kemiskinan Di Indonesia Tahun 1986-2015. Universitas Negeri Yogyakarta.

Jonaidi A. (2012). Analisis Pertumbuhan Ekonomi dan Kemiskinan Di Indonesia. 1.

Kartini, K. (2005). Pemimpin dan Kepemimpinan.

Kuciswara, D., Muslihatinningsih, F., \& Santoso, E. (2021). Pengaruh Urbanisasi, Tingkat Kemiskinan, Dan Ketimpangan Pendapatan Terhadap Kriminalitas Di Provinsi Jawa Timur. Https://Ojs.Unpkediri.Ac.Id/Index.Php/Ak untansi/Article/View/16307/2254, 6(3). https://doi.org/10.29407/jae.v6i3.16307

Kuncoro, M. (2006). Ekonomi Pembangunan Teori, Masalah dan Kebijakan.

Mantra. (2007). Demografi Umum.

Nanga, M. (2001). Teori Makro Ekonomi Masalah dan Kebijakan (1st ed.).

Purwanti, E. Y., \& Widyaningsih, E. (2019). Analisis Faktor Ekonomi Yang Mempengaruhi Kriminalitas Di Jawa Timur. Jurnal Ekonomi-Qu, 9(2). https://doi.org/10.35448/jequ.v2i2.7165

Putra, A. D., Martha, G. S., Fikram, M., \& Yuhan, R. J. (2021). Faktor-Faktor yang Memengaruhi Tingkat Kriminalitas di Indonesia Tahun 2018. Indonesian Journal of Applied Statistics, 3(2), 123. https://doi.org/10.13057/ijas.v3i2.41917

Rahmalia, S., Ariusni, \& Triani, M. (2019). Pengaruh Tingkat Pendidikan, Pengangguran, Dan Kemiskian Terhadap 
Kriminalitas Di Indonesia. 3.

Sabiq, R. M., \& Apsari, N. C. (2021). Dampak Pengangguran Terhadap Tindakan Kriminal Ditinjau Dari Perspektif Konflik. Jurnal Kolaborasi Resolusi Konflik, 3(1), 51.

https://doi.org/10.24198/jkrk.v3i1.31973

Sadono, S. (2011). Makro Ekonomi Teori Pengantar.

Silvia, \& Ikhsan. (2021). Pengaruh Pertumbuhan Ekonomi, Kemiskinan Dan Kepadatan Penduduk Terhadap Kriminalitas Di Indonesia. 6(1), 23-30.

Suwandi. (2015). Desentralisasi Fiskal Dan Dampaknya Terhadap Pertumbuhan Ekonomi, Penyerapan Tenaga Kerja, Kemiskinan, Dan Kesejahteraan di Kabupaten/Kota Induk Provinsi Papua (1st ed.).

Todaro, Michael, P. (2000). Pembangunan Ekonomi di Dunia Ketiga (7th ed.).

Todaro, M. . dan S. S. C. (2003). Pembangunan Ekonomi Di Dunia Ketiga (8th ed.).

Wahid, M., Mustikawan, A., \& Ridho, A. (2010). Evaluasi Pembelajaran: Kompetensi dan Praktik. 